\title{
Analisis Usaha Ayam Broiler Yang Menggunakan Prebiotik Immuno Forte
}

(The Broiler Chicken Business Analysis Using Immuno Forte Prebiotics)

\author{
Agus setiawan ${ }^{1}$, Mira delima $^{1}$, Samadi $^{1}$ \\ ${ }^{1}$ Program Studi Peternakan, Fakultas Pertanian, Universitas Syiah Kuala
}

\begin{abstract}
Abstrak. Tujuan penelitian ini adalah untuk mengetahui pengaruh penggunaan Prebiotik Immuno Forte ${ }^{\circledR}$ terhadap usaha ternak ayam broiler. Penelitian ini dilakukan di Laboratorium Lapangan Peternakan (LLP) Jurusan Peternakan Universitas Syah Kuala, Banda Aceh dari tanggal 22 Agustus sampai 21 September 2015. Penelitian ini menggunakan 100 ekor DOC ayam broiler CP 707 strain arbor acres produksi PT. Charoen Pokphand. Ransum yang digunakan dalam penelitian ini adalah ransum komersial $R_{511}$ HI PRO VITE periode starter dan $R_{512}$ Bravo periode finisher. Perlakuan dalam penelitian ini adalah level Immuno forte ${ }^{\circledR}$ dalam air minum terdiri dari yang terdiri dari 5 perlakuan yaitu P0 $\left(0 \mathrm{~mL}\right.$ Immuno forte ${ }^{\circledR} / 3 \mathrm{~L}$ air $), \mathrm{P} 1(0,5 \mathrm{~mL}$ Immuno forte ${ }^{\circledR} / 3 \mathrm{~L}$ air), P2(1 mL Immuno forte ${ }^{\circledR} / 3 \mathrm{~L}$ air), P3 (1.5 mL Immuno forte ${ }^{\circledR} / 3 \mathrm{~L}$ air) dan P4 (2 mL Immuno forte ${ }^{\circledR} / 3 \mathrm{~L}$ air). Setiap perlakuan terdiri dari 4 ulangan sehingga diperoleh 20 unit perlakuan. Hasil penelitian menunjukkan bahwa penambahan Immuno forte ${ }^{\circledR}$ dalam air minum selama pemeliharaan memberikan hasil yang berbeda terhadap total biaya produksi. Biaya produksi tertinggi terdapat pada perlakuan P1 (Rp) 143.761, dan yang terendah P2 (Rp) 140.250, dan B/C ratio tertinggi pada P3 1,39, dan terendah pada P2, 1,24. Hasil dari penelitian ini, penggunaan Immuno forte sebagai prebiotik dalam air minum broiler pada semua perlakuan layak untuk dilanjutkan sebagai usaha ternak ayam broiler.
\end{abstract}

Kata kunci : analisis usaha, ayam broiler, prebiotik, dan immuno forte ${ }^{\circledR}$.

Abstract. The purpose of this experiments is to obtain the effect of prebiotic Immuno forte ${ }^{\circledR}$ on broiler enterprise. This experiment was conducted at Field Laboratory of Animal Husbandry (LLP), Animal Husbandry Department, Syiah Kuala University, Banda Aceh from $22^{\text {nd }}$ August to $21^{\text {st }}$ September 2015. Totally, 100 of day old chickens (DOC) from CP 707 Strain Arbor Acres produced from PT. Charoen Pokphand were used in this study. Commercial feed of R511 HI PRO VITE for starter period and R512 Bravo for finisher was used in this experiment. This study consisted of 5 treatments and 4 replications. The treatment in this study was the level of prebiotic in the drinking water P0 $\left(0 \mathrm{~mL}\right.$ Immuno forte ${ }^{\circledR} / 3 \mathrm{~L}$ in drinking water), P1 $\left(0,5 \mathrm{~mL}\right.$ Immuno forte ${ }^{\circledR} / 3 \mathrm{~L}$ in drinking water), P2(1 mL Immuno forte ${ }^{\circledR} / 3 \mathrm{~L}$ in drinking water), P3 $\left(1.5 \mathrm{~mL}\right.$ Immuno forte ${ }^{\circledR} / 3 \mathrm{~L}$ in drinking water) and P4 (2 mL Immuno forte ${ }^{\circledR} / 3 \mathrm{~L}$ in drinking water). The results of the study indicated that the level of Immuno forte ${ }^{\circledR}$ in the drinking water significantly influenced on total production cost. The highest production costs are in treatment P1 (Rp) 143 761, and the lowest P2 (Rp) 140 250, and B / C ratio P3 highest at 1.39, and the lowest in P2, 1.24. The results of this study, the use of Immuno forte as a prebiotic in the broiler drinking water at all feasible to continue treatment as broiler chicken farming.

Keywords: business analysis, broiler, prebiotic and immuno forte ${ }^{\circledR}$.

\section{PENDAHULUAN}

Pembangunan subsektor peternakan merupakan bagian dari pembangunan pertanian yang bertujuan untuk menyediakan pangan hewani berupa daging, susu, dan telur, meningkatkan pendapatan peternak, meningkatkan devisa dan memperluas kesempatan kerja, sehingga pada masa yang akan datang diharapkan dapat memberikan kontribusi yang nyata dalam pembangunan perekonomian bangsa. Untuk meningkatkan penyediaan protein hewani asal ternak terutama daging ayam, maka peranan ayam broiler sebagai salah satu komoditi ternak penghasil daging sudah tidak disanksikan lagi kehadirannya dalam memenuhi kebutuhan masyarakat akan protein hewani, sebab ayam broiler memiliki percepatan tumbuh yang cepat dengan berat badan yang tinggi mampu mengimbangi laju kebutuhan masyarakat yang semakin tinggi pula. Di samping itu, dengan harga yang lebih murah daging ayam dapat mensubtitusi kebutuhan daging yang berasal dari ternak besar maupun ternak kecil (Cahyono, 2001).

Pertumbuhan optimal dari ayam broiler harus ditunjang oleh berbagai faktor, seperti pakan, pengontrolan penyakit, bibit yang unggul dan juga manajemen yang baik. Pakan merupakan salah satu faktor yang memegang peranan yang sangat penting, kerena berbagai 
zat makanan yang dibutuhkan oleh tubuh berasal dari pakan. Ketersediaan pakan bagi tubuh tidak hanya ditunjang dari kandungan nutrisi dalam pakan yang diformulasi, tetapi juga tergantung dari berapa banyak bahan pakan tersebut dapat dicerna oleh ternak (Rasyaf, 1994). Penggunaan bahan pakan aditif seperti antibiotik untuk meningkatkan daya cerna telah banyak dilakukan, namun penggunaan bahan pakan tersebut telah dilarang sejak beberapa tahun terakhir karena efek negative yang ditimbulkannya (Cervantes, 2007).

Immuno forte ${ }^{\circledR}$ merupakan salah satu produk prebiotik komersil berbentuk cairan, yang diberikan dalam air minum berfungsi untuk meningkatkan daya cerna melaui modifikasi mikro organisme dalam saluran pencernaan, mengikat mikotoksin, dan mencegah atau mengurangi stress . Produk Immuno forte ${ }^{\circledR}$ mengandung 3 komponen pertahanan yang dibutuhkan unggas yaitu mannanoligosaccharide (MOS), beta glucans, dan chitosan (Royalpoultry, 2013).

\section{METODELOGI PENELITIAN}

\section{Tempat dan Waktu}

Penelitian ini dilaksanakan di Laboratotium Lapangan Peternakan (LLP), Jurusan Peternakan, Fakultas Perttanian Universitas Syiah Kuala, Banda Aceh. Penelitian ini berlangsung dari tanggal 22 Agustus sampai dengan 19 September 2015.

\section{Materi Penelitian}

Dalam penelitian ini digunakan sebanyak 100 (seratus) ekor day old chicken (DOC) ayam broiler CP 707 strain Arbor Acres, produksi PT. Charoen Pokphand Medan.

\section{Bahan dan Alat}

Bahan yang digunakan dalam penelitian ini terdiri dari ransum komersial $\left(\mathrm{R}_{511}\right.$ hi pro vite dan $\mathrm{R}_{512}$ bravo), Prebiotik Immuno forte ${ }^{\circledR}$, vaksin Newcastle Disease (ND) berupa Medivac ND La Sota, desinfektan Rodalon, litter, koran bekas, dan kapur. Sementara peralatan yang akan digunakan dalam penelitian ini meliputi tempat pakan, tempat minum, chickquard, kandang bersekat ukuran $70 \times 70 \mathrm{~cm}$, dan lampu pemanas sebanyak 20 unit, timbangan, termometer dan peralatan penunjang kandang seperti ember, cangkul, gayung, sprayer, dan kereta sorong masing masing 1 unit.

\section{Perlakuan}

Ransum yang digunakan dalam penelitian ini berupa ransum komersial yaitu $\mathrm{R}_{511}$ hi pro vite untuk anak ayam umur 0-3 minggu (starter) dan $\mathrm{R}_{512}$ bravo untuk anak ayam umur 3-5 minggu (grower/finisher). Sementara perlakuan dalam penelitian ini berupa penambahan level prebiotik Immuno forte ${ }^{\circledR}$ yang dilarutkan dalam air minum masing-masing sebanyak 0.5-2.0 $\mathrm{mL} / 3 \mathrm{~L}$ air berdasarkan tiap-tiap perlakuan.

\section{Rancangan Penelitian}

Penelitian ini menggunakan Rancangan Acak Lengkap (RAL) yang terdiri atas 5 perlakuan dan 4 ulangan. Setiap ulangan merupakan unit percobaan yang masing-masing terdiri atas 20 (dua puluh) ekor ayam broiler. Perlakuan yang diberikan adalah penggunaan prebiotik Immuno forte ${ }^{\circledR}$ yang dicampurkan ke dalam air minum. 
Tabel 3. Bagan Rancangan Penelitian

\begin{tabular}{cccccc}
\hline Ulangan & \multicolumn{5}{c}{ Perlakuan } \\
\cline { 2 - 6 } & $\mathrm{P}_{0}$ & $\mathrm{P}_{1}$ & $\mathrm{P}_{2}$ & $\mathrm{P}_{3}$ & $\mathrm{P}_{4}$ \\
\hline 1 & $\mathrm{P}_{0} .1$ & $\mathrm{P}_{1} .1$ & $\mathrm{P}_{2} .1$ & $\mathrm{P}_{3} .1$ & $\mathrm{P}_{4.1}$ \\
2 & $\mathrm{P}_{0} .2$ & $\mathrm{P}_{1} .2$ & $\mathrm{P}_{2} .2$ & $\mathrm{P}_{3} .2$ & $\mathrm{P}_{4.2}$ \\
3 & $\mathrm{P}_{0} .3$ & $\mathrm{P}_{1} .3$ & $\mathrm{P}_{2} .3$ & $\mathrm{P}_{3} .3$ & $\mathrm{P}_{4} .3$ \\
4 & $\mathrm{P}_{0} .4$ & $\mathrm{P}_{1} .4$ & $\mathrm{P}_{2} .4$ & $\mathrm{P}_{3} .4$ & $\mathrm{P}_{4.4}$ \\
\hline
\end{tabular}

Ket: $\mathrm{P}_{0}$ Prebiotik immuno forte ${ }^{\circledR} 0 \mathrm{~mL} / 3 \mathrm{~L}$ air (kontrol), $\mathrm{P}_{1}$ Prebiotik immuno forte ${ }^{\circledR} 0.5 \mathrm{~mL} / 3$ $\mathrm{L}$ air, $\mathrm{P}_{2}$ Prebiotik 1.0mL/L air, $\mathrm{P}_{3}$ Prebiotik immuno forte ${ }^{\circledR} 1.5 \mathrm{~mL} / 3 \mathrm{~L}$ air, $\mathrm{P}_{4}$ Prebiotik immuno forte ${ }^{\circledR} 2.0 \mathrm{~mL} / 3 \mathrm{~L}$ air.

\section{Pelaksanaan Penelitian}

Penelitian ini akan dilakukan dalam tiga tahap, yaitu:

a. Tahap Persiapan.

Pelaksanaan penelitian diawali dengan pembersihan kandang dan pengapuran alas kandang. Setelah proses pembersihan selesai maka dilakukan pemasangan sekat sesuai jumlah ulangan dalam perlakuan yaitu sebanyak 20 petak, mengisi litter pada setiap kandang, pemasangan chickquard, koran sebagai alas, lampu pijar (40 watt) sebagai pemanas pada setiap kandang dan penempatan tempat pakan dan tempat minum dan pengacakan kandang dengan tiap petak kandang masing-masing diisi oleh 5 ekor ayam DOC.

b. Tahap Pemeliharaan.

Ayam diberi pakan dan air minum ad libitum. Setiap hari (pagi) dilakukan penimbangan pakan yang diberikan dan sisa pakan untuk mengetahui jumlah pakan yang dikonsumsi, pada periode starter (0-3 minggu) diberikan pakan ransum komersial $\mathrm{R}_{511}$ hi pro vite dan Pada periode grower/finisher (3-4 minggu) diberikan ransum komersial $\mathrm{R}_{512}$ bravo. Air minum diukur dua kali sehari ( pagi dan sore), meliputi pengukuran air pada perlakuan $\mathrm{P}_{0}, \mathrm{P}_{1}, \mathrm{P}_{2}, \mathrm{P}_{3}$ dan $\mathrm{P}_{4}$ yang ditambahkan prebiotik Immuno forte ${ }^{\circledR}$ masing-masing $0,0.5$, 1.0, 1.5, $2.0 \mathrm{~mL} / 3 \mathrm{~L}$ air dan sisa air minum untuk mengetahui konsumsi dari air minum. Vaksin yang diberikan adalah jenis ND la Sota pada umur 4 hari secara tetes mata dan diulang pada umur 18 hari secara injeksi intramuskuler pada dada, kedua vaksin dilakukan pada sore hari. Penimbangan terhadap bobot badan ayam dilakukan setiap seminggu sekali.

\section{Parameter}

\section{Biaya Produksi}

Biaya produksi dihitung dengan cara menjumlahkan seluruh biaya faktor-faktor produksi yaitu biaya tetap dan biaya tidak tetap. Biaya tetap terdiri dari kandang, (tempat pakan dan peralatan). Sedangkan biaya tidak tetap terdiri dari biaya pembelian DOC, pakan komersial, immuno forte, vitamin, vaksin, biaya tenaga kerja, dan lain sebagainya.

\section{Nilai Pendapatan}

Nilai pendapatan diperoleh dari hasil produksi. Nilai pendapatan merupakan penerimaan kotor yang diperoleh dari perkalian antara hasil penjualan ayam yang dihasilkan dengan harga yang berlaku di pasar. 


\section{Keuntungan}

Keuntungan diperoleh dari hasil penjualan akhir dikurangi dengan total biaya produksi. Untuk mengetahui seberapa besar keuntungan yang diperoleh dari usaha ayam broiler digunakan rumus menurut Soekartiwi (2006) :

Rumus :

$$
\mathrm{K}=\mathrm{TR}-\mathrm{TC}
$$

Keterangan : $\mathrm{K}=$ Keuntungan

$$
\begin{array}{ll}
\text { Total Revenue } & =\text { Total penerimaan } \\
\text { Total Cost } & =\text { Total pengeluaran }
\end{array}
$$

\section{Nilai Analisis Benefit Cost Ratio (B/C Ratio)}

Nilai analisi Benefit Cost Ratio diperoleh dengan cara membagi nilai pendapatan dengan biaya produksi.

Menurut Cahyono (2002) analisis tingakat kelayakan usaha B/C ratio (Benefit Cost Ratio) bisa digunakan dalam analisis kelakan usaha, yaitu perbandingan antara pendapatan dan total biaya yang dikeluarkan.

$$
\mathrm{B} / \mathrm{C}=\frac{\text { Total Hasil Produksi }(\mathrm{Rp})}{\text { Total Biaya Produksi (Rp) }}
$$

Benefit Cost Ratio adalah penilaian yang dilakukan untuk melihat tingkat efisiensi penggunaan biaya berupa perbandingan jumlah nilai bersih sekarang yang positif dengan jumlah nilai bersih sekarang yang negatif, atau dengan kata lain Net B/C adalah perbandingan antara jumlah NPV positif dangan jumlah NPV negatif dan ini menunjukkan gambaran berapa kali lipat benefit akan kita peroleh dari cost yang kita keluarkan (Gray, 1997).

\section{HASIL DAN PEMBAHASAN}

\section{Biaya Produksi}

Biaya produksi adalah total biaya yang dikeluarkan dalam proses produksi untuk mengolah bahan baku menjadi produksi akhir (Ivana, 2004). Perhitungan biaya produksi adalah aspek yang sangat penting dalam menjalankan suatu usaha peternakan. Perhitungan biaya produksi menjelaskan tentang perkiraan pendapatan yang akan diterima. Menurut Siregar dan Samadhi (1988), biaya produksi dibagi dalam dua klasifikasi utama yaitu biaya tetap dan biaya tidak tetap.

\section{Biaya Tetap (Fixad Cost)}

Biaya tetap dalam penelitian ini adalah biaya penyusutan kandang (termasuk didalamnya tempat pakan, tempat minum, dan alal-alat yang digunakan dalam penelitian), yang hasilnya dapat dilihat pada Tabel 4 berikut ini.

Tabel 4. Biaya Penyusutan Kandang (Rp.)

\begin{tabular}{cccccc}
\hline \multirow{2}{*}{ ULANGAN } & \multicolumn{5}{c}{ PERLAKUAN } \\
\cline { 2 - 6 } & P0 & P1 & P2 & P3 & P4 \\
\hline 1 & 3.835 & 3.835 & 3.835 & 3.835 & 3.835 \\
2 & 3.835 & 3.835 & 3.835 & 3.835 & 3.835
\end{tabular}




$\begin{array}{llllll}3 & 3.835 & 3.835 & 3.835 & 3.835 & 3.835 \\ 4 & 3.835 & 3.835 & 3.835 & 3.835 & 3.835\end{array}$

Kandang yang digunakan dalam penelitian adalah kandang permanen dimana dinding kandang tersebut berupa setengah beton dan setengah kawat untuk aliran udara. Kandang berlantaikan semen dengan atap kandang menggunakan bahan seng.

Perhitungan finansial berkaitan dengan kandang bersifat asumtif, yaitu harga kandang Rp 40.000.000,-, kandang dapat digunakan selama 40 tahun, sehingga penyusutan kandang adalah $2,5 \%$ per tahun. Total biaya penyusutan kandang selama penelitian (28 hari) adalah Rp. 76.712,32,-. Karena kandang digunakan bersama oleh semua unit penelitian, maka biaya per unit penelitiannya juga sama yaitu Rp. 3.835,-. Perhitungan biaya penyusutan kandang dapat dilihat pada Lampiran 1.

\section{Biaya Tidak Tetap (Variable Cost)}

Biaya tidak tetap dalam penelitian ini adalah biaya pembelian DOC, pembelian bahanbahan pakan termasuk immuno forte sebagai bahan perlakuan penelitian, pembelian vitamin dan obat-obatan serta biaya penggunaan listrik dan pembayaran tenaga kerja.

\section{Biaya Pembelian DOC}

DOC yang digunakan pada penelitian ini berjumlah 100 ekor. Setiap unit penelitian berisi lima ekor DOC dengan harga per ekornya Rp. 6.000,- (berdasarkan harga pasar saat penelitian). Karena setiap unit penelitian berisi jumlah DOC yang sama, maka biaya yang dikeluarkan untuk pembelian DOC per unit penelitian juga sama, yaitu Rp. 30.000,-. Tabel 5 berikut adalah biaya yang digunakan pada penelitian ini untuk pembelian DOC. Sedangkan rincian perhitungannya dapat dilihat pada Lampiran 2.

Tabel 5. Biaya Pembelian DOC (Rp.)

\begin{tabular}{cccccc}
\hline \multirow{2}{*}{ ULANGAN } & \multicolumn{5}{c}{ PERLAKUAN } \\
\cline { 2 - 6 } & P0 & P1 & P2 & P3 & P4 \\
\hline 1 & 30.000 & 30.000 & 30.000 & 30.000 & 30.000 \\
2 & 30.000 & 30.000 & 30.000 & 30.000 & 30.000 \\
3 & 30.000 & 30.000 & 30.000 & 30.000 & 30.000 \\
4 & 30.000 & 30.000 & 30.000 & 30.000 & 30.000 \\
\hline
\end{tabular}

\section{Biaya Pembelian Pakan}

Biaya pembelian pakan dalam penelitian ini terdiri atas dua macam yaitu biaya pakan starter dan biaya pakan finisher.

\section{Biaya Pembelian Pakan Starter}

Pakan starter diberikan selama 14 hari, mulai dari hari pertama sampai dengan hari ke 14. Perhitungan konsumsi pakan dilakukan dengan cara mengurangi jumlah pakan yang diberikan dengan jumlah pakan yang tersisa setiap hari. Jumlah total konsumsi pakan starter selama 14 hari dapat dilihat pada Tabel 6.

Tabel 6. Konsumsi Pakan Starter Selama 14 Hari (Gram) 


\begin{tabular}{cccccc}
\hline & P0 & P1 & P2 & P3 & P4 \\
\hline 1 & 4.740 & 4.538 & 4.490 & 4.680 & 4.830 \\
2 & 4.875 & 4.654 & 4.568 & 4.754 & 4.786 \\
3 & 4.645 & 4.780 & 4.699 & 4.703 & 4.750 \\
4 & 4.787 & 4.634 & 4.708 & 4.588 & 4.764 \\
\hline Total & 19.047 & 18.606 & 18.465 & 18.725 & 19.130 \\
\hline Rata-Rata & 4.762 & 4.652 & 4.616 & 4.681 & 4.783 \\
\hline
\end{tabular}

Tabel 6 menjelaskan bahwa tingkat konsumsi pakan starter dipengaruhi oleh pemberian prebiotik Immuno forte melalui air minum. Nilai rataan konsumsi ransum tertinggi didapat pada perlakuan pemberian Immuno forte $2 \mathrm{ml}$ (P4), diikuti kontrol (P0) dan pemberian 1,5 ml pada (P3). Pada perlakuan pemberian Immuno forte $1 \mathrm{ml}(\mathrm{P} 2)$ menunjukkan angka konsumsi ransum paling rendah. Hal ini terjadi diperkirakan karena pengaruh tingkat pemberian prebiotik Immuno forte.

Biaya penggunaan pakan starter selama 14 hari diperoleh dari hasil perkalian jumlah total konsumsi pakan masing-masing unit penelitian dengan harga pakan per kg sesuai dengan masing masing perlakuan. Total biaya penggunaan pakan starter selama 14 hari dapat dilihat pada Tabel 6. Sedangkan rincian perhitungannya dijelaskan pada Lampiran 3.

Tabel 7. Biaya Pakan Starter Selama 14 Hari Penelitan (Rp.)

\begin{tabular}{cccccc}
\hline \multirow{2}{*}{ ULANGAN } & \multicolumn{5}{c}{ PERLAKUAN } \\
\cline { 2 - 5 } & P0 & P1 & P2 & P3 & P4 \\
\hline 1 & 35.550 & 34.035 & 33.675 & 35.100 & 36.225 \\
2 & 36.562 & 34.905 & 34.260 & 35.655 & 35.895 \\
3 & 34.837 & 35.850 & 35.242 & 35.272 & 35.625 \\
4 & 35.902 & 34.755 & 35.310 & 34.410 & 35.730 \\
\hline \multicolumn{7}{c}{ Total } & 142.851 & 139.545 & 138.487 & 140.437 \\
\hline
\end{tabular}

\section{Biaya Pembelian Pakan Finisher}

Pakan finisher diberikan selama 14 hari, sejak hari ke 15 sampai dengan hari ke 28 atau pada masa akhir penelitian. Perhitungan konsumsi pakan dilakukan dengan cara mengurangi 
jumlah pakan yang diberikan dengan jumlah pakan yang tersisa setiap hari. Jumlah total konsumsi pakan starter selama 14 hari dapat dilihat pada Tabel 8.

Tabel 8. Konsumsi Pakan Finisher Selama 14 Hari (Gram)

\begin{tabular}{cccccc}
\hline \multirow{2}{*}{ ULANGAN } & \multicolumn{5}{c}{ PERLAKUAN } \\
\cline { 2 - 6 } & $\mathrm{P} 0$ & $\mathrm{P} 1$ & $\mathrm{P} 2$ & $\mathrm{P} 3$ & $\mathrm{P} 4$ \\
\hline 1 & 5.810 & 6.232 & 6.185 & 6.545 & 6.202 \\
2 & 5.915 & 6.826 & 6.187 & 6.272 & 6.452 \\
3 & 6.245 & 6.780 & 6.136 & 6.429 & 6.530 \\
4 & 6.173 & 6.516 & 6.017 & 6.100 & 6.596 \\
\hline Total & 24.143 & 26.354 & 24.525 & 25.346 & 25.780 \\
\hline Rata-Rata & 6.036 & 6.589 & 6.131 & 6.337 & 6.445 \\
\hline
\end{tabular}

Tabel 8 menjelaskan bahwa tingkat konsumsi pakan finisher dipengaruhi oleh pemberian prebiotik Immuno forte melalui air minum. Nilai rataan konsumsi ransum tertinggi didapat dari perlakuan pemberian Immuno forte $0,5 \mathrm{ml}(\mathrm{P} 1)$, diikuti dengan perlakuan pemberian Immuno forte $2 \mathrm{ml}(\mathrm{P} 4)$ dan pemberian 1,5 ml pada (P3). Perlakuan kontrol menunjukkan angka konsumsi ransum finisher paling rendah. Hal ini terjadi diperkirakan karena perlakuan kontrol tidak diberikan prebiotik Immuno forte.

Biaya penggunaan pakan finisher selama 14 hari diperoleh dari hasil perkalian jumlah total konsumsi pakan masing-masing unit penelitian dengan harga pakan per kg sesuai dengan masing masing perlakuan. Total biaya penggunaan pakan finisher selama 14 hari dapat dilihat pada Tabel 9. Sedangkan rincian perhitungannya dijelaskan pada Lampiran 4.

Tabel 9. Biaya Pakan Finisher Selama 14 Hari Penelitan (Rp.)

\begin{tabular}{cccccc}
\hline \multirow{2}{*}{ ULANGAN } & \multicolumn{5}{c}{ PERLAKUAN } \\
\cline { 2 - 6 } & P0 & P1 & P2 & P3 & P4 \\
\hline 1 & 41.251 & 44.247 & 43.913 & 46.469 & 44.034 \\
2 & 41.999 & 48.464 & 43.927 & 44.531 & 45.809 \\
3 & 44.339 & 48.138 & 43.565 & 45.645 & 46.363 \\
4 & 43.828 & 46.263 & 42.720 & 43.310 & 46.831 \\
\hline Total & 171.417 & 187.112 & 174.125 & 179.955 & 183.037 \\
\hline Rata-Rata & 42.854 & 46.778 & 43.531 & 44.989 & 45.759 \\
\hline
\end{tabular}

Dari Tabel 9 dapat dilihat bahwa pengeluaran total biaya untuk pembelian pakan finisher tertinggi ditunjukkan oleh perlakuan P2, sedangkan yang terendah adalah perlakuan kontrol. Pola pengeluaran biaya pembelian pakan finisher diantara perlakuan-perlakuan menunjukkan hal yang sejalan dengan pola yang diperlihatkan oleh tingkat konsumsi pakan. Oleh karena itu, biaya pakan yang dikeluarkan berkaitan dengan tingkat konsumsi pakan.

\section{Biaya Pembelian Vitamin, Obat-obatan dan Immuno Forte}

Biaya pembelian vitamin dan obat-obatan untuk setiap unit penelitian adalah sama. Ketetapan tersebut ditentukan berdasarkan kesamaan perlakuan pemberian vitamin dan obatobatan yang diterima oleh setiap unit penelitiannya. Selain itu, setiap kandang unit penelitian diisi dengan jumlah DOC yang juga sama (lima ekor). Sedangkan biaya penggunaan immuno forte untuk setiap unit penelitian ditetapkan sama, walaupun kuantitas pemakaian untuk setiap unit kandang penelitiannya berbeda. Ketetapan tersebut ditentukan berdasarkan penggunaan immuno forte yang secara keseluruhan relatif sedikit, disamping harganya yang relatif murah. 
Oleh karena itu, perhitungan rinci biaya penggunaan immuno forte diabaikan untuk kemudian dilakukan alternatif perhitungan dengan pendekatan yang lebih sederhana. Tabel 10 berikut menunjukan biaya yang dikeluarkan untuk pembelian vitamin, obat-obatan dan immuno forte.

Sedangkan rincian perhitungannya dapat dilihat pada Lampiran 5.

Tabel 10. Biaya PembelianVitamin, Obat-obatan dan Immuno Forte (Rp.)

\begin{tabular}{cccccc}
\hline \multirow{2}{*}{ ULANGAN } & \multicolumn{5}{c}{ PERLAKUAN } \\
\cline { 2 - 6 } & P0 & P1 & P2 & P3 & P4 \\
\hline 1 & 4.060 & 4.060 & 4.060 & 4.060 & 4.060 \\
2 & 4.060 & 4.060 & 4.060 & 4.060 & 4.060 \\
3 & 4.060 & 4.060 & 4.060 & 4.060 & 4.060 \\
4 & 4.060 & 4.060 & 4.060 & 4.060 & 4.060 \\
\hline
\end{tabular}

\section{Biaya Pembayaran Tenaga Kerja}

Penelitian ini menggunakan satu orang tenaga kerja. Standar satu orang tenaga kerja dapat menangani 2500 ekor ayam, mulai dari DOC sampai saat siap potong dengan upah Rp. 1.900.000,-/bulan. Hal ini mengacu kepada ketentuan Peraturan Menteri Tenaga Kerja dan Transmigrasi pada tahun 2015 yaitu Upah Minimum Provinsi (UMP) Aceh sebesar Rp 1.900.000,-/orang/bulan. Lama pemeliharaan selama penelitian adalah 28 hari. Maka untuk kapasitas ayam sebanyak 100 ekor, biaya tenaga kerja per bulannya adalah Rp. $76.000,-$. Sehingga besarnya upah tenaga kerja per unit penelitian dapat ditentukan Tabel 10. Perincian perhitungan biaya tenaga kerja untuk setiap unit penelitian dapat dilihat pada Lampiran 5. Tabel 11. Biaya Pembayaran Tenaga Kerja (Rp.)

\begin{tabular}{cccccc}
\hline \multirow{2}{*}{ ULANGAN } & \multicolumn{5}{c}{ PERLAKUAN } \\
\cline { 2 - 6 } & P0 & P1 & P2 & P3 & P4 \\
\hline 1 & 3.547 & 3.547 & 3.547 & 3.547 & 3.547 \\
2 & 3.547 & 3.547 & 3.547 & 3.547 & 3.547 \\
3 & 3.547 & 3.547 & 3.547 & 3.547 & 3.547 \\
4 & 3.547 & 3.547 & 3.547 & 3.547 & 3.547 \\
\hline
\end{tabular}

\section{Biaya Pemakaian Listrik}

Tabel 12. Biaya pemakain listrik selama 28 hari.

\begin{tabular}{cccccc}
\hline \multirow{2}{*}{ Ulangan } & \multicolumn{5}{c}{ Perlakuan } \\
\cline { 2 - 6 } & P0 & P1 & P2 & P3 & P4 \\
\hline 1 & 20.655 & 20.655 & 20.655 & 20.655 & 20.655 \\
2 & 20.655 & 20.655 & 20.655 & 20.655 & 20.655 \\
3 & 20.655 & 20.655 & 20.655 & 20.655 & 20.655 \\
4 & 20.655 & 20.655 & 20.655 & 20.655 & 20.655 \\
\hline
\end{tabular}

Dari tabel 12 dapat lihat yang bahwa pemakain listrik selama 28 hari, biaya pemakian lisrik untuk setiap unit penelitian Rp. 20.655,-. Karena setiap unit biaya listrik yang digunakan dalam penelitian ini adalah sama, maka biaya per unit penelitian sama yaitu Rp. 20.655,-.. Perhitungan biaya penggunaan litrik dapat dilihat pada Lampiran 7. 


\section{Total Biaya Produksi}

Biaya produksi menurut Mulyadi (2000) adalah Biaya-biaya yang terjadi untuk mengolah bahan baku menjadi produk jadi yang siap dijual. Biaya produksi merupakan semua biaya yang berhubungan dengan fungsi produksi untuk menghasilkan barang jadi. Biaya produksi adalah salah satu elemen yang penting dalam aktivitas produksi dari suatu perusahaan untuk mendapatkan laba.

Total biaya produksi merupakan semua biaya yang dikeluarkan selama penelitian yang dihitung dengan cara menjumlahkan seluruh pengeluaran baik dari komponen biaya tetap maupun biaya tidak tetap, dan dihitung dalam satuan rupiah seperti dapat dilihat pada Tabel 12.

Tabel 13. Total Biaya Produksi (Rp.)

\begin{tabular}{cccccc}
\hline \multirow{2}{*}{ ULANGAN } & \multicolumn{5}{c}{ PERLAKUAN } \\
\cline { 2 - 6 } & P0 & P1 & P2 & P3 & P4 \\
\hline 1 & 138.898 & 140.379 & 139.685 & 143.666 & 142.356 \\
2 & 140.658 & 145.466 & 140.284 & 142.283 & 143.801 \\
3 & 141.273 & 146.085 & 140.904 & 139.929 & 144.085 \\
4 & 141.827 & 143.115 & 140.127 & 143.014 & 144.658 \\
\hline Total & 562.656 & 575.045 & 561.000 & 548.892 & 574.900 \\
\hline Rata-Rata & 140.664 & 143.761 & 140.250 & 142.223 & 143.725 \\
\hline
\end{tabular}

Dari Tabel 13 dapat dilihat bahwa setiap unit penelitian memperlihatkan besaran biaya produksi yang berbeda. Hal ini disebabkan Karena adanya perbedaan biaya yang dikeluarkan untuk setiap factor produksi dari setiap unit penelitian. Perlakuan P1 (Rp. 143.761,-) merupakan perlakuan dengan rata-rata biaya produksi tertinggi, sedangkan perlakuan P2 (Rp. 140.250,-) merupakan yang paling rendah.

\section{Nilai Penjualan}

Penjualan adalah total keseluruhan hasil penerimaan yang dihitung dari perkalian antara jumlah satuan hasil produksi dengan satuan harga yang berlaku (Prawirokusumo, 1983). Produksi karkas tiap unit penelitian dapat dilihat pada Lampiran 8. Harga jual per kilogram karkas adalah Rp. 24.000,-. Setelah dilakukan perhitungan maka didapatlah nilai penjualan dari setiap unit penelitiannya

Tabel 14. Harga Penjualan Karkas Ayam (Rp)

\begin{tabular}{cccccc}
\hline \multirow{2}{*}{ ULANGAN } & \multicolumn{5}{c}{ PERLAKUAN } \\
\cline { 2 - 6 } & P0 & P1 & P2 & P3 & P4 \\
\hline 1 & 198.240 & 187.200 & 176.400 & 187.200 & 195.120 \\
2 & 184.080 & 195.600 & 184.080 & 197.760 & 207.360 \\
3 & 195.360 & 204.072 & 170.880 & 183.120 & 199.920 \\
4 & 182.160 & 192.240 & 166.560 & 199.680 & 190.080 \\
\hline Total & 759.840 & 779.112 & 697.920 & 767.760 & 792.480 \\
\hline Rata-Rata & 189.960 & 194.778 & 174.480 & 191.940 & 198.120 \\
\hline
\end{tabular}


Nilai penjualan rata-rata tertinggi terdapat pada perlakuan P4 (Rp. 198.120,-) dan ratarata penjualan terendah ada pada perlakuan P2 (Rp. 174.480,-). Nilai penjualan sangat dipengaruhi oleh berat karkas, semakin tinggi berat karkas maka nilai penjualan akan semakin tinggi.

\section{Keuntungan}

Keuntungan suatu perusahaan didapatkan dari hasil penjualan produk setelah dikurangi dengan biaya-biaya yang dikeluarkan perusahaan untuk memproduksi produk tersebut. Analisis keuntungan ini bertujuan untuk mengetahui besarnya keuntungan dari usaha yang dilakukan. Tingkat keuntungan juga digunakan untuk mengetahui apakah suatu usaha layak atau tidak untuk diusahakan kembali (Kuswadi,2005).

Tabel 15 berikut menjelaskan adanya keuntungan yang dihasilkan dari usaha pemeliharaan ayam broiler yang menambahkan Immuno Forte pada air minumnya. Hasil penelitian menunjukkan bahwa keuntungan paling tinggi ditunjukkan oleh P4 (2 ml), sedangkan yang terendah ditunjukkan oleh P2 $(1 \mathrm{ml})$. Harga jual karkas ayam berpengaruh langsung terhadap besar kecilnya jumlah keuntungan.

Tabel 15. Keuntungan (Rp.)

\begin{tabular}{cccccc}
\hline \multirow{2}{*}{ ULANGAN } & \multicolumn{5}{c}{ PERLAKUAN } \\
\cline { 2 - 6 } & P0 & P1 & P2 & P3 & P4 \\
\hline 1 & 59.342 & 46.821 & 36.715 & 43.534 & 52.764 \\
2 & 43.422 & 50.134 & 43.796 & 55.477 & 63.559 \\
3 & 54.087 & 57.987 & 29.976 & 43.191 & 55.835 \\
4 & 40.333 & 49.125 & 26.433 & 56.666 & 45.422 \\
\hline Total & 197.184 & 204.067 & 136.920 & 198.868 & 217.580 \\
\hline Rata-Rata & 49.296 & 51.017 & 34.230 & 49.717 & 54.395 \\
\hline
\end{tabular}

\section{Analisis Benefit Cost Ratio (B/C Ratio)}

Benefit/Cost ratio adalah merupakan perbandingan antara total penerimaan dengan total biaya. Semakin besar B/C ratio maka akan semakin besar pula keuntungan yang diperoleh petani mengalokasikan faktor produksi dengan lebih efiisien (Soekartawi,2003).

Dengan demikian benefit cost ratio menunjukkan manfaat yang diperoleh setiap penambahan satu rupiah pengeluaran. B/C akan menggambarkan keuntungan dan layak dilaksanakan jika mempunyai $\mathrm{B} / \mathrm{C}>1$. Apabila $\mathrm{B} / \mathrm{C}=1$, maka usaha tersebut tidak untung dan tidak rugi, sehingga terserah kepada penilai pengambil keputusan dilaksanakan atau tidak. ApabilaB/C $<1$ maka usaha tersebut merugikan sehingga lebih baik tidak dilaksanakan (Gittinger, 1986).

Tabel 16. Analisis Benefit Cost Ratio (B/C Ratio) Ayam penelitian

\begin{tabular}{ccccc}
\hline Perlakuan & Total Produksi & Total Pendapatan & B/C & Ket \\
\hline P0 & 562.656 & 759.840 & 1,35 & Layak \\
P1 & 575.045 & 779.112 & 1,35 & Layak \\
P2 & 561.000 & 697.920 & 1,24 & Layak
\end{tabular}




$\begin{array}{lllll}\text { P3 } & 548.892 & 767.760 & 1,39 & \text { Layak } \\ \text { P4 } & 574.900 & 792.480 & 1,37 & \text { Layak }\end{array}$

Perhitungan B/C ratio memperlihatkan bahwa pada semua tingkat perlakuan dari $\mathrm{P} 0-\mathrm{P} 4$ yang bahwa layak untuk dilanjutkan sebagai usaha ayam broiler. Hal tersebut disebabkan karena $\mathrm{B} / \mathrm{C}$ ratio yang diperoleh mencapai satu. Bila menunjukan nilai $\mathrm{B} / \mathrm{C}$ ratio lebih dari satu, yang artinya usaha ayam broiler bisa dilanjutkan sebagai usaha.

Sebagaimana pendapat Djamin (1989), menyatakan bahwa bila ratio antara penerimaan dengan biaya produksi lebih besar dari pada satu maka usaha tersebut dapat dilanjutkan, tetapi bila lebih kecil dari satu maka usaha tersebut tidak dapat dilanjutkan, karena menyebabkan kerugian. Apabila $\mathrm{B} / \mathrm{C}$ ratio sama dengan satu maka usaha tersebut mengalami titik pulang pokok. Kartasudjana dan Edjeng (2006) menyatakan bahwa analisis pendapatan usaha digunakan untuk menggambarkan faktor keuntungan usaha dari ratio penerimaan dari biaya produksi.

\section{KESIMPULAN}

Penggunaan Immuno forte sebagai prebiotik dalam air minum ayam broiler memberi pengaruh yang menguntungkan bagi usaha ternak ayam broiler. Hal ini dapat diketahui dari hasil analisis finansial yang memperlihatkan bahwa nilai B/C ratio semua perlakuan adalah lebih dari satu. Sehingga penggunaan Immuno forte sebagai prebiotik dalam air minum broiler pada semua perlakuan layak untuk dilanjutkan sebagai usaha ternak ayam broiler.

\section{SARAN}

Perlu dilakukan penelitian lebih lanjut terhadap penggunaan Immuno forte sebagai tambahan dalam air minum ayam broiler pada usaha ternak ayam broiler dengan skala usaha yang lebih besar. Karena selain ada kemungkinan meningkatkan efisiensi cost value, juga tingkat keuntungan usaha dan kelayakan usaha akan lebih meningkat.

\section{DAFTAR PUSTAKA}

Cahyono, B, 2001. Cara Meningkatkan Budidaya Ayam Ras Pedaging.

Cahyono, B. 2002. Wortel Teknik Budi Daya Analisis Usaha Tani. Kanisius, Yogyakarta.

Cervantes, H. 2007. Antibiotic Feed Additives: Politics and Science. Phibro Animal Health,Watkinsville, Georgia, USA.

Djamin. 1989. Evaluation of methanol-grown bacteria as a source of protein and energy for young chicks. British Poultry Science. 17 : 393-401.

Gittinger. 1986. Analisa Ekonomi Proyek-Proyek Pertanian. Penerjemah Slamet Gray,C.F dan Larson,E.W.(1997). Project Management. First Edition. Irwin McGraw-Hill, Boston

Ivana, Eva. 2004. “Analisis Penentuan Harga Pokok Produksi Karkas dengan Menggunakan Metode Full Costing dan Activity Based Costing Studi Kasus Rumah Potong Ayam Asia Afrika, Bogor, Jawa Barat". Skripsi.Jurusan Ilmu-Ilmu Sosial Ekonomi Pertanian. Fakultas Pertanian. Institut Pertanian Bogor. Bogor

Kartasudjana, R dan Edjeng S. 2006. Manajemen Ternak Unggas. Penebar Swadaya. Jakarta 
Kuswadi, 2005. Meningkatkan Keuntungan Dengan Pendekatan Akuntasi Keuangan Dan Akuntasi Biaya. Jakarta: PT Elex Media Komputindo.

Mulyadi. 2000. Akuntansi Biaya Edisi 5. Yogyakarta: Aditya Media.

Prawirokusumo. 1983. Ilmu Nutrisi dan Makanan Unggas, Salemba Empat. Jakarta.

Rasyaf. 1994. Makanan Ayam Broiler. Kanisius: Yogyakarta.

Royalpoultry.2013.(http://royalpoultry.co/blog/2013/12/01/immuno-forte-prebiotik

prebiotic-untuk-meningkatkan-daya-tahan-tubuh-dari-stres-dan-penyakit/. Di akses tanggal 1 juli 2015.

Siregar dan Samadhi, 1988. Analisa Kandungan Bahan Kering, Protein Kasar dan Total Digestible Nutrisi Cassapro pada Lama Pengeraman yang Berbeda. Skripsi. Fakultas Peternakan Universitas Muhammadiyah Malang.

Soekartawi, 2003. Prinsip Ekonomi Pertanian. Rajawali Press. Jakarta.

Soekartawi. 2006. Analisis Usahatani. UI Press, Jakarta.

\section{LAMPIRAN}

\section{Lampiran 1}

Biaya Penggunaan Kandang (Rp.) dengan Asumsi Penyusutan Kandang Sebesar 2,5 \% Per Tahun

Harga kandang Rp. 40.000.000,- (termasuk gudang dan peralatan)

- Persentase penyusutan kandang

Error! Reference source not found. $=2,5 \% /$ tahun

- Biaya kandang selama 1 tahun adalah

Error! Reference source not found. $x$ Rp.40.000.000,- $\quad=$ Rp. $1.000 .0000,-$ /tahun

- Biaya kandang selama 28 hari penelitian adalah

Error! Reference source not found.

28 hari x Rp. 2.739,73,-/hari

$$
=\text { Rp. 76.712,32,- }
$$

- Biaya untuk tiap unit kandang selama penelitian adalah

Error! Reference source not found.

$=$ Rp. 3.835,6,-/unit kandang

\section{Lampiran 2}

\section{Harga DOC (Rp.) Setiap Unit Kandang Penelitian}


- Harga DOC/kotak

$=$ Rp. 600.000.-

- Harga DOC/ekor

Error! Reference source not found.

$=$ Rp. 6.000.-/ekor

- Harga DOC/unit penelitian

Rp.6000,- x 5 DOC/unit = Rp. 30.000,-/unit kandang

\section{Lampiran 3}

\section{Biaya pakan starter (Rp)}

Jumlah konsumsi pakan starter hari 1-15 (Gram)

\begin{tabular}{cccccc}
\hline \multirow{2}{*}{ Ulangan } & \multicolumn{5}{c}{ Perlakuan } \\
\cline { 2 - 6 } & P0 & P1 & P2 & P3 & P4 \\
\hline 1 & 4.740 & 4.538 & 4.490 & 4.680 & 4.830 \\
2 & 4.875 & 4.654 & 4.568 & 4.754 & 4.786 \\
3 & 4.645 & 4.780 & 4.699 & 4.703 & 4.750 \\
4 & 4.787 & 4.634 & 4.708 & 4.588 & 4.764 \\
\hline Total & 19.047 & 18.606 & 18.465 & 18.725 & 19.130 \\
Rata-Rata & 4.762 & 4.652 & 4.616 & 4.681 & 4.783 \\
\hline
\end{tabular}

Biaya pembelian pakan starter Error! Reference source not found.(Rp)

\begin{tabular}{cccccc}
\hline \multirow{2}{*}{ Ulangan } & \multicolumn{5}{c}{ Perlakuan } \\
\cline { 2 - 6 } & P0 & P1 & P2 & P3 & P4 \\
\hline 1 & 35.550 & 34.035 & 33.675 & 35.100 & 36.225 \\
2 & 36.562 & 34.905 & 34.260 & 35.655 & 35.895 \\
3 & 34.837 & 35.850 & 35.242 & 35.272 & 35.625 \\
4 & 35.902 & 34.755 & 35.310 & 34.410 & 35.730 \\
\hline Total & 142.851 & 139.545 & 138.487 & 140.437 & 143.475 \\
Rata-Rata & 35.713 & 34.886 & 34.622 & 35.109 & 35.869 \\
\hline
\end{tabular}

- Biaya pakan P0 = Harga pakan : Error! Reference source not found. = Rp. 7,5,- $\times$ $4.762=$ Rp. 35.713,- 
- Biaya pakan P1 = Harga pakan : Error! Reference source not found. = Rp. 7,5,- $\times$ $4.652=$ Rp. 34.886,-

- Biaya pakan P2 = Harga pakan : Error! Reference source not found. = Rp. 7,5,- $\times$ 4.616= Rp. 34.622,-

- Biaya pakan P3 = Harga pakan : Error! Reference source not found. = Rp. 7,5,- $\times$ 4.681= Rp. 35.109,-

- Biaya pakan P4 = Harga pakan : Error! Reference source not found. = Rp. 7,5,- $\times$ $4.783=$ Rp. 35.869,-

\section{Lampiran 4}

\section{Biaya pakan finisher $(\mathbf{R p})$}

Jumlah konsumsi pakan finisher hari 1-15 (Gram)

\begin{tabular}{cccccc|}
\hline \multirow{2}{*}{ Ulangan } & \multicolumn{5}{c|}{ Perlakuan } \\
\cline { 2 - 6 } & P0 & P1 & P2 & P3 & P4 \\
\hline 1 & 5.810 & 6.232 & 6.185 & 6.545 & 6.202 \\
2 & 5.915 & 6.826 & 6.187 & 6.272 & 6.452 \\
3 & 6.245 & 6.780 & 6.136 & 6.429 & 6.530 \\
4 & 6.173 & 6.516 & 6.017 & 6.100 & 6.596 \\
\hline Total & 24.143 & 26.354 & 24.525 & 25.346 & 25.780 \\
Rata-Rata & 6.036 & 6.589 & 6.131 & 6.337 & 6.445 \\
\hline
\end{tabular}

Biaya pembelian Pakan Finisher Error! Reference source not found. (Rp.)

\begin{tabular}{cccccc|}
\hline \multirow{2}{*}{ Ulangan } & \multicolumn{5}{c|}{ Perlakuan } \\
\cline { 2 - 6 } & $\mathrm{P} 0$ & $\mathrm{P} 1$ & $\mathrm{P} 2$ & $\mathrm{P} 3$ & $\mathrm{P} 4$ \\
\hline 1 & 41.251 & 44.247 & 43.913 & 46.469 & 44.034 \\
2 & 41.999 & 48.464 & 43.927 & 44.531 & 45.809 \\
3 & 44.339 & 48.138 & 43.565 & 45.645 & 46.363 \\
4 & 43.828 & 46.263 & 42.720 & 43.310 & 46.831 \\
\hline Total & 171.417 & 187.112 & 174.125 & 179.955 & 183.037 \\
Rata-Rata & 42.854 & 46.778 & 43.531 & 44.989 & 45.759 \\
\hline
\end{tabular}

- Biaya pakan P0 = Harga pakan : Error! Reference source not found. $=$ Rp. $7,1,-\times$ 6.036= Rp. 42.854,-

- Biaya pakan P1 = Harga pakan : Error! Reference source not found. = Rp. 7,1,- $\times$ $6.589=$ Rp. 46.778,-

- Biaya pakan P2 = Harga pakan : Error! Reference source not found. = Rp. 7,1,- $\times$ 6.131= Rp. 43.531,-

- Biaya pakan P3 = Harga pakan : Error! Reference source not found. = Rp. 7,1,- $\times$ $6.337=$ Rp. 44.989,-

- Biaya pakan P4 = Harga pakan : Error! Reference source not found. = Rp. 7,1,- $\times$ $6.445=$ Rp. $45.759,-$

\section{Lampiran 5}


Biaya Immuno forte Vitamin dan Obat-obatan (Rp.) Selama Penelitian

- Vita chick : 2

- Vita stres : 2

- Vaksin : 1

- Immuno forte : $176 \mathrm{ml}$

- Vita chick : $2 \times 1.000=$ Rp. $2.000,-$

- Vita stres : $2 \times 1.000=$ Rp. 2.000,-

- Vaksin ND : $1 \times 42.000=$ Rp. 42.000,-

- Immuno forte : $176 \mathrm{ml}=\underline{\text { Rp. } 35.200,-}$ Total

Rp. 81.200

\section{Keterangan}

Error! Reference source not found. $=$ Rp. $200,-\times 176=$ Rp. 35.200,-

\section{Lampiran 6}

\section{Perhitungan Biaya Tenaga Kerja}

Tenaga kerja 1 orang untuk 100 ekor selama penelitian (28 hari)

- Upah 1 orang tenaga untuk menangani 2.500 ekor broiler $=$ Rp. 1.900.000,-/bulan

Error! Reference source not found. $x$ Rp.1.900.000,- $\quad=$ Rp. 76.000,-/bulan

- Upah 1 orang tenaga kerja per hari

Error! Reference source not found. $\quad=$ Rp. $2.533,33,-/$ hari

- Upah tenaga kerja selama 28 hari

$$
\text { Rp. 2.533,33,- x } 28 \text { hari= Rp.70.933,33,-/100 ekor }
$$

- Upah tenaga kerja per unit kandang penelitian

$$
\text { Error! Reference source not found. = Rp.3.546,66,-/Unit }
$$

\section{Lampiran 7}

\section{Perhitungan Biaya Listrik Selama penelitian (28 hari)}

75 watt $=18$ hari

45 watt $=10$ hari

- Lampu 75 watt Rata-rata Pemakain (9 Jam)/hari

Error! Reference source not found. $=0,075(\mathrm{kwh}) \times 9($ jam $)=0,675 \times \mathrm{Rp}$. $1.350 /(\mathrm{kwh})$ 
$=$ Rp. $911,25 /$ (hari) $x 18$

$=$ Rp. $16.402,5$

- Lampu 45 watt Rata-rata Pemakain (7 Jam)/hari

Error! Reference source not found. $=0,045(\mathrm{kwh}) \times 7($ jam $)=0,315 \times \mathrm{Rp} .1 .350$.(kwh)

$=$ Rp. 425,25(hari) $x 10$

$=$ Rp. $4.252,5$

- Pemakaian Lampu/Listrik ( unit) Selama Penelitian 28 (hari)

18 (hari) 75 watt $=$ Rp. $16.402,5+$

10 (hari) 45 watt $=$ Rp. $4.252,5$

Pemakain/ Unit = Rp. $20.655 \times 20$ Unit

$=$ Rp. 413.100

\section{Lampiran 8.}

Produksi karkas tiap unit penelitian (gram)

\begin{tabular}{cccccc}
\hline & \multicolumn{5}{c}{ Perlakuan } \\
\cline { 2 - 6 } Ulangan & $\mathrm{p} 0$ & $\mathrm{p} 1$ & $\mathrm{p} 2$ & $\mathrm{p} 3$ & $\mathrm{p} 4$ \\
\hline 1 & 8.260 & 7.800 & 7.350 & 7.800 & 8.130 \\
2 & 7.670 & 8.150 & 7.670 & 8.240 & 8.460 \\
3 & 8.140 & 8.503 & 7.120 & 7.630 & 8.330 \\
4 & 7.590 & 8.010 & 6.940 & 8.320 & 7.920 \\
\hline Total & 31.660 & 32.463 & 29.080 & 31.990 & 32.840 \\
\hline Rata-rata & 7.915 & $8.115,75$ & 7.270 & $7.997,5$ & 8.210 \\
\hline
\end{tabular}

